\title{
QUEEN'S
UNIVERSITY
BELFAST
}

\section{Rejuvinating method}

Lisle, D. (2014). Rejuvinating method. Critical Studies on Security, 2(3), 370-373.

https://doi.org/10.1080/21624887.2014.982404

\section{Published in:}

Critical Studies on Security

\section{Document Version:}

Peer reviewed version

Queen's University Belfast - Research Portal:

Link to publication record in Queen's University Belfast Research Portal

\section{Publisher rights}

(C) 2014 York University

This is an Accepted Manuscript of an article published by Taylor \& Francis in Critical Studies on Security on 17 Dec 2014, available online: http://www.tandfonline.com/doi/full/10.1080/21624887.2014.982404

\section{General rights}

Copyright for the publications made accessible via the Queen's University Belfast Research Portal is retained by the author(s) and / or other copyright owners and it is a condition of accessing these publications that users recognise and abide by the legal requirements associated with these rights.

\section{Take down policy}

The Research Portal is Queen's institutional repository that provides access to Queen's research output. Every effort has been made to ensure that content in the Research Portal does not infringe any person's rights, or applicable UK laws. If you discover content in the Research Portal that you believe breaches copyright or violates any law, please contact openaccess@qub.ac.uk. 


\section{Rejuvinating Method:}

Method is no longer a dirty word for critical security scholars. ${ }^{1}$ It used to be that we were on the losing end of any conversation about methods as departmental colleagues looked at us with confusion or open hostility when we uttered the words 'discourse analysis', 'genealogy', or - the very worst - 'deconstruction'. I recently had the following conversation with a young, newly-appointed colleague:

HE: (noticing the bags under my eyes): what are you working on?

ME: I'm trying to revise an article. It's about the Bali bomb and the role of tourism in the War on Terror.

HE: When are you going?

ME: Sorry?

HE: When are you going to Bali?

ME: Uh... I'm not

HE: [look of bafflement]

ME: Uh... I'm looking at how a global mode of response to the Bali bomb required the securitization of the entire tourism industry

HE: ... but .... How are you.... Who are you interviewing?

ME: I'm not doing interviews.

HE: Oh [it finally dawned on him that I was one of 'those people'. He shook his head at me with a mixture of pity and scorn, and then walked away].

I'm sure many readers have had similar conversations with colleagues over the years - some more snarky, some more patronizing, and some more violent than this relatively benign encounter. However, my frustration at not standing up for myself during this conversation has prompted some thinking about the positive contributions of critical security studies - how it has helped to open up the discipline of IR (i.e. what we analyse), and how it has clarified new research methods in the process (i.e. how we analyse). So here is what I should have said to my patronizing colleague:

\section{WHAT we analyse:}

We have expanded the terrain of research: As part of the critical turn that irrevocably changed IR in the early 1990s, critical security studies has helped to radically open up the terrain of what counts as a valid research object in the discipline. 'Security' is no longer about guns, bombs, world order and strategy: it is also about culture, technology, mobility, media productions, identity, protest, science, geographical imaginaries, solidarity, ethics and everyday life (to name just a few). This opening up is important for discussions about method because many of these new objects cannot be analysed through traditional methods they require new concepts, new thinking, and new ways of doing research.

We have troubled the traditional role of disciplinary gatekeepers: With such an expanded field of analysis, it became more difficult for 'experts' to control the research agenda. New identities can now speak authoritatively about issues usually thought to be outside of security concerns; for example, feminists speak 
about sexual violence during war, political economists track the financing of terrorist networks, and post-structuralists show how impositions of security after 9/11 produced new forms of governance and control. I'm not saying, here, that critical security studies is free of its own internal struggles over who counts as an 'expert' and who can speak authoritatively about security; indeed, there are patriarchs, charlatans and power-grabbers in every school of thought. But I am saying that part of the remit of critical thinking in general is to pluralize, diversify and disseminate expertise within the discipline. And it is precisely this pluralization that opens new spaces for new kinds of methods.

We have instigated important cross-disciplinary conversations: critical security scholars have been wilfully disobedient of disciplinary boundaries in that they have sought inspiration from across the social sciences, humanities and natural sciences. For example; from philosophers we learn how to conceptualize speechacts to help us work through processes of securitization; from literary theorists we learn how dominant discourses of security mobilize and reproduce themselves; and from scholars in media studies and visual culture we learn how media conventions reify a global cartography of safety and danger. These crossdisciplinary conversations are important because they put us in touch with new research methods and help us resuscitate conventional research methods in a critical frame.

\section{HOW we analyse:}

Visual, Discursive and Narrative Frames: critical security studies has done a great deal of excellent work showing how dominant discourses are reproduced visually, verbally and textually. We have traced productions and reproductions of dominant security discourses in government policy papers, political speeches, websites, publicity documents, films, novels, comic books, theatre productions, travelogues, video games, television commercials, You Tube memes and advertisements. Thanks to our unashamed borrowing from literary, visual, cultural and media scholars, we have become especially good at figuring out how visual symbols and narrative arcs work to secure consensus around contentious decisions aimed at guaranteeing national or global security. The methods used in this work are a mixture of semiotic and discourse analysis, and range from the very detailed thematic coding of documents (e.g. through the work of Fairclough) to the more conceptual analysis of how truth claims, identities and threats are articulated (e.g. using a Foucauldian genealogy). ${ }^{2}$ This work has shown over and over again that the line between reality and representation has been irrevocably blurred, and that both are mutually constitutive. To my patronizing colleague, then, I should have stood on the shoulders of my allies in critical security studies and explained that the 'reality' of Bali (including its inhabitants and visitors) is itself constituted by pre-formed security discourses that cannot be escaped.

Materialities, Spaces and Site-Specific Ethnography: While the various critical turns in IR - discursive, visual, narrative - brought new and exciting research, they also brought their own limitations. Our success at discourse analysis has privileged the written, spoken and visualized over embodied encounters and 
routine practices. It has become beholden to language and image at the expense of understanding what happens when bodies collide in various global spaces. While it galls me to admit it, perhaps my patronizing colleague had a point about 'going there'. Indeed, some of the most exciting recent work in critical security studies borrows from anthropology and takes its critical disposition 'into the field'. ${ }^{3}$ Detailed observations of what actually happens at specific sites such as airports and borders offer extremely rich and textured accounts of the multiple forces mobilized by discourses of security. As Mark B. Salter has argued with respect to airports, Foucauldian concepts such as governmentality, heterotopia and assemblage have been enormously helpful for scholars seeking to foreground the embodied, material and spatial aspects of discourse. ${ }^{4}$ By paying close attention to what actually happens in a specific site - how bodies are oriented and governed, how they are entangled with one another and with nonhuman systems - we are identifying how security works in the register of everyday life. Indeed, security takes hold most intensely where we least expect it - in our intimate lives, our leisure time, our financial transactions, our travel plans, and in the way we behave towards Others not like us.

Conversational Tactics: Along with complimenting discourse analysis with ethnography and observation, critical security scholars have also resuscitated the art of interviewing. Increased attention to ethical considerations (e.g. interviewing vulnerable groups) has, conversely, been accompanied by a relaxing of formal interview conventions. Indeed, conversations with security agents, policy-makers, securitized subjects and the makers and users of security technologies are much less formal and more wide-ranging than traditional semistructured interviews. This is largely because our efforts to trouble the role of the 'expert' include both interviewer and interviewee: we problematize how expertise are constructed and maintained in certain fields, and we critically reflect on our own tendencies to behave as authorities, experts and knowledge brokers. Because both interlocutors stand to learn something about the other in the process, these conversations do not assume a one-way transfer of knowledge.

The best work in critical security studies, it seems to me, is that which folds these and other methods together in an effort to gain an understanding of how security is currently reducing freedom and constraining agency. This is an accretive process of critical learning: it is important that we don't jettison the lessons learned by text, language and image as we go 'into the field' or learn to talk to an array of experts and agents. Rather, what needs to happen more coherently in critical security studies is that insights from our excellent discursive analyses need to be brought into a much wider field of perception by collapsing textimage-world together. Indeed, the final retort to my disdainful colleague should have been, "But didn't you know? I am already in Bali!"

\footnotetext{
${ }^{1}$ This resurgence of debates over method is best expressed in Mark B. Salter and Can E. Mutlu, eds. Research Methods in Critical Security Studies: An Introduction (London: Routledge, 2013) and the ESRC funded project International Collaboratory on Critical Methods in Security Studies, see http://www.open.ac.uk/ccig/files/ccig/iccm_project-description.pdf (accessed 04/02/14) 2 For discourse analysis using detailed thematic coding, see Norman Fairclough, Analysing Discourse: Textual Analysis for Social Research (London: Routledge, 2003) and (with Isabella
} 
Fairclough) Political Discourse Analysis: A Method for Advanced Students (London: Routledge, 2012). For more conceptual understandings of discourse analysis, see Barry Hindess, Discourses of Power: From Hobbes to Foucault (Oxford: Wiley-Blackwell, 1995), and David Howarth, Aletta Norval and Yannis Stavrakakis, eds., Discourse Theory and Political Analysis: Identities, Hegemonies and Social Change (Manchester: Manchester University Press, 2000)

${ }^{3}$ Here, I am speaking about critical anthropology that emerged out of similar foundational debates in the 1990s, best expressed in James Clifford, The Predicament of Culture: TwentiethCentury Ethnography, Literature, and Art (Harvard: Harvard University Press, 1988) and James Clifford and George Marcus, eds., The Poetics and Politics of Ethnography (Berkeley: University of California Press, 2010).

${ }^{4}$ Mark B. Salter, 'Introduction: Airport Assemblage', in Mark B. Salter, ed. Politics at the Airport (Minneapolis: University of Minnesota Press, 2008). 